\title{
The Effectiveness of Project Based Learning Method In Local History Learning Using The Document-Archive Of Bima Sultanate In 1930-1950 To Improve Source Critical Ability Of Students
}

\author{
Sumiyati ${ }^{1}$, Sariyatun ${ }^{1}$, Leo Agung $S^{1}$ \\ ${ }^{1}$ Postgraduate Student of History Education at Sebelas Maret University \\ Email: sumimaci068@gmail.com
}

\begin{abstract}
This study aims to find out the effectiveness of the implementation of Project Based Learning $(\mathrm{PjBL})$ in local history learning by using document-archive of Bima Sultanate as an effort to improve source critical ability of students. From the research, it was revealed that Project Based Learning is strongly effective to motivate students to be more active in analyzing the document archive as the learning sources of local history. This study is using research and development method. The result showed that students provided treatment had the increase in analyzing the source critical ability rather than those with no treatment. The related source analysis was the relevant source about local history. The learning of local history became a prominent aspect because it always relates to national history, particularly in term of the nation identity as a whole. In the learning activity, the material of local history is always linked to the locality of certain place; it aims as an effort of reinforcement on the comprehension and critical analysis of students toward local history that relates to national history. According to the observation that was conducted in STKIP Yapis Dompu-NTB as the location of research, it was found that the learning of local history had not been optimal implemented as its purpose. It was brought about by the lacking of the appropriate sources such as references and teaching materials in which the students having less understanding of source critical analysis and archive material were not taught about those, so that the ability of source critical analysis was not adequate. The learning of local history in STKIP Yapis Dompu-NTB needed to employ document archive as the learning source. This was not only to stimulate source critical analysis but also to make the local history subject became more variety. Moreover, it could motivate students and educators to write scientific article productively. The using of Project Based Learning is expected could help in comprehending the concept and teaching materials.
\end{abstract}

Keywords: PjBL method, document archive, local history

\section{INTRODUCTION}

\section{Background}

The history subject has a very strategic meaning in the formation of Indonesian people who have a sense of nationality and love of the country. as a rich country, Indonesia has locality values such as in oral tradition and past time, and today locality 
values are beginning to remember because they contain the philosophical values, customs and customs prevailing in the community, and local wisdom becomes a glue in the relationship This is reinforced by the point of view of Sartono Kartodirdjo in Susanto [23] who said that in the framework of nation-building, teaching history does not merely serve to provide historical knowledge as a collection of historical fact information but also aims to awaken the students or awaken their historical awareness, To achieve the goal must then that should put forward the values of life is not just memorize the name, place and number of years only.

The existence of regional history in history learning has a function to strengthen national history through the elaboration and appointment of regional roles in national constellations. Beyond these two boundaries of national and regional history, the emergence of local history, according to Abdullah [1] is defined as "the history of a place", a locality, whose limits are determined by the covenant of the historian. The author has the freedom to define the limits of writing, whether with geographical scope, ethnic, broad or narrow. Local history is elastic, can speak of a village, a district, a district, an ethnic residence, a tribe, in one region or several regions. In addition Sartono Kartodirdjo in Soedarsono [8] also said that the utilization of local history at any educational level will enable learners in learning history to resonate with the eigenwelt aspect.

The use of archives-document in history learning is not a strange thing because remembering the main source in the writing of history is the archive-document. In this case historians are required to have the ability to reconstruct the past in the form of narrative descriptions must be balanced with the ability to process findings in the form of document-archives and as a perfecting in it also required historians have the ability of source criticism so that will not be stuck in the subjectivity of the author. To reconstruct a historical event into a meaningful and valuable event of the history of the aforementioned plot called the historical method becomes an important component.

Verification in historical research is identical to source criticism which is a way of seeking the authenticity or source of the source and to assess whether the source has credibility or not. This is in line with what L. Gottschalk reveals that the Criticism of the source of history is an attempt to gain the authenticity and credibility of the source by doing intellectual and rational work that follows the historical methodology in order to gain the objectivity of an event.

In teaching and learning process, it needs to have a method or a certain way as a medium in the delivery of learning. Soekanto in Trianto suggested that the learning model is a conceptual framework that delineates systematic procedures in organizing learning experiences to achieve certain learning goals, and serves as a learning designer and lecturers in planning teaching and learning activities. The learning model is a conceptual framework that teachers use as a guide in the learning process to achieve the objectives of learning as expected. In this case, the project-based method is chosen as one of the methods in the study in this study, as it is known that the project based learning model has its own advantages in the project-based learning model prioritizes the learner's participation because this model is in the constructivism sphere.

Project-Based Leaning Model becomes very important in teaching and learning process to improve students' academic ability. Broadly speaking, the PjBL model provides opportunities for student-centered, more collaborative and student-engaging learning systems that are actively involved in completing projects independently and working with teams and integrating real problems. The PjBL model employs students 
to complete projects independently and work together in teams, thereby helping students adjust to their future work environment.

In history learning at the college, the role of archives or documents is very important because it relates to the writing of scientific papers either in the form of thesis, articles or as a scientific work that is part of community service by academics in a college. In this case the College of Teacher Training and Education of Yapis Dompu which is a private educational institution in Dompu Regency that realized its importance of learning history opened the department of historical education. Department of History Education is one of the favourite majors and in the learning process there is a course of local history. Researchers interested in conducting research on the development of learning models Local History based Archives-Documents to improve students' source criticism analysis at History Study Program of STKIP Yapis Dompu. From the background has been described previously, "How the effectiveness of project based learning model in the learning of local history using the archive-document of Bima Sultanate in 1930-1950 to improve the ability of students' source criticism.

\section{Research Method}

The type of research used is Research and Development (R \& D). According to Borg and Gall [3] Research and Development Model is "a process used and validate educational product". This research is also called "Research based development" which emerged as a strategy and aims to increase the quality of education. In addition to developing and validating educational outcomes, Research and development also aims to find new knowledge through basic research to answer specific questions about practical problems through applied research that are used to improve the practice, $\mathrm{R} \&$ $\mathrm{D}$ education practices are utilized to produce skills training models for empowerment.

The type of data used consists of qualitative and quantitative data. Both data were obtained by interview, observation, and responses from students conducted in preliminary study used to compile the draft model to be developed, as well as comments and input from expert or expert team to improve the model to be developed. While the quantitative data obtained from the achievement test to see the student's academic ability is the ability of source criticism analysis. Achievement tests are used in the final stages of each learning process. Test used to measure the achievement of learning objectives. Araif Furchon describes the test is a set of stimulus given to someone with the intention to get answers that can be used as a basis for determining the score of numbers

\section{Discussion of Research Result}

\section{LOCAL HISTORY LEARNING IN THE CLASSROOM}

Local history course is a course for fifth semester students. Learning process runs as many as 16 meetings, consisting of 14 times face-to-face in the classroom and 2 times the evaluation namely examination of middle semester and examination of final semester. One time meeting of Local History Course is held in 100 minutes or two Credit Semester Unit (SKS). The standard of competence and basic competence of local history courses are adapted to pre-colonial history up to the history of existing contemporary material with local history. 
The standard of competence to be achieved in the local history course is understanding and analyzing the local history of the region of Sumbawa Island from the early days of the Kingdom to the end of Colonial domination. The basic competence (KD) in local history course consists of: understanding and analyzing Local history in the early days of the kingdom, understanding and analyzing the Islamization process of Sumbawa Island (1600), understanding and analyzing post eruption of Tambora 18151830, understanding and analyzing Colonialization of Bima and Dompu Sultanate (1900-1920), understanding and analyzing the period of Japanese Occupation (19421945), understanding and analyzing the final period of colonial domination and the process of Integration of Bima Sultanate in Indonesia. Sources of the materials used by lecturers in local history course are Bima history text books that lecturers provide reference books to students to use independently.

Learning process of local history course includes the beginning, middle, and closing activities. In the beginning activity, educator explains the purpose of learning and gives appreciation in accordance with prepared teaching materials. The method used is lecture method, discussion, group presentation and Q \& A. The most commonly used method is the lecture method. In closing activities, lecturer ends the lecture with reflection in the form of Q \& A session with the students. In the lecturers' group presentations act as facilitators by assisting the discussions and providing input and emphasis on important materials. Form of evaluation given by lecturers in the form of group assignments that are presented in the classroom on local history course.

In the local history course, lecturer and student experience some barriers during the learning process takes place. The obstacles that often faced by lecturers in the process of learning are: (1) sources of local history materials are still lacking, (2) low reading interest in students, (3) limited ability of students in reading source of teaching materials. While the obstacles faced by students include: (1) lack of reading sources about local history materials, (2) many learning resources obtained from the internet, so that students have less analysis of the sources obtained. The obstacles that exist in the process of learning local history can be overcome by providing several alternatives as a solution so that learning is not merely delivering learning materials but fun and intelligent students in achieving success in the test.

Thus the researcher in this case draw the general conclusion that local history learning applied in history education program at STKIP Yapis Dompu is still experiencing barriers in learning because of limited teaching materials so that students get difficulties in completing task given by lecturer. This can certainly be solved by the variety of learning resources provided especially in the learning of local history, leaving the source and archives owned by the local government of Bima available in the Bima regional library. Given the variety of learning resources that are expected to give a good response to students to be more motivated in deepening local history from local sources in the form of archives or documents that will provide understanding and train students in developing the analytical skills they have.

\section{STUDENTS' SOURCE CRITICISM ABILITY OF STKIP YAPIS-DOMPU}

The result of field research that has been conducted by using interviews with the lecturers and students and analyzed the data obtained, the source criticism ability of the students of History STKIP-Yapis Dompu is still low, it is also seen from the result of 
scientific work such as thesis and other lecture duties. There are some students who have written about local history in their scientific work in the thesis, but the sources used in the writing are more sources are obtained from blogs on the internet without including a valid source. The use of primary sources is very less even can be said no, secondary sources in the form of Bima history books only some directly related to the theme and title of the scientific work, so in the work there is almost no criticism what else the analysis of criticism of the theory -theories related to the paper. The course of local history is a compulsory subject programmed in the fifth semester students, students have a special interest in this course. This is because this course is a course that provides knowledge and insight for them about the history of their region

The knowledge and historical writing cannot be separated from the archives and historical sources as suggested by Sartono Kartodirdjo the key to entering the area of history is through historical sources such as inscriptions, documents, letters, all of which are records of human activity. (Roeslan Abdul Gani: 1980: 12) In the course of local history presented in the lecturer class only gives some references in the same local history books every year, it directly makes the students unable to explore with knowledge of local and regional history. While local history can be maximized to explore the history of the region. Ideally in the course of local history, lecturers provide examples of primary sources and secondary sources of history that students should know specifically, it can provide a stimulus for students in improving the source criticism because by using various sources students will get a lot of information that will bring them to be able to analyze the information. The use of archival-documents as a source of history is still very poorly conducted by students. It is because the lecture does not refer to the primary source as the source. This is very unfortunate considering the primary source of history can help students in understanding the soul of the era of an event. Document archives are very helpful for students to know the condition or circumstances of the time, but of course by relying on the ability of source critic and student interpretation so that later will lead to the form of writing history.

The ability of students' source criticism of History Study Program at STKIP Yapis Dompu is still low, this is because students are not yet accustomed in using various sources as a source of writing scientific papers, the use of sources that only come from the internet make the students do not criticize the sources of information obtained, It is a source that is owned only limited to secondary sources in the form of history books and do not use the primary source at all. The method of studying history is not really considered as a technique and step in producing scientific papers of history so that in the assignment and writing of scientific papers in the form of historical writing, especially local history tend to be a collection of information from the theme or title that exists. Analysis and interpretation are hardly found in the writing of such scientific papers. There are many things that influence the low source criticism of the students, but the most dominant is the source of learning and teaching materials of local history. Students cannot even distinguish the primary source of history and the secondary source of history.

Development steps, first with the initial sketch models of learning, the second draft of the model is validated by a team of expert, from here obtained some feedback then conducted a revision by the researchers, the third draft of the revised model from the results input by a team of experts in the test in small groups, there is advice and input to do repairs, revision of the results of the small group tested in large group, from here the 
researchers still doing revisions, recently conducted a test of effectiveness after do revisions back to actually be implemented in the class wants.

\section{LEARNING MODEL DEVELOPMENT OUTCOMES}

\section{Model Expert Validation}

Local history-based learning model of project based learning designed to improve students' source criticism using archive documents of the era of the Sultanate of Bima as a source of history and historical learning resources.

The learning model developed should be validated to the expert team, tested and then implemented. The validation of the learning model aims to determine whether the model is feasible or not to be applied to the experimental class. Validation of learning model is conducted with expert team, first with scale 4 with number of indicator 28 obtained the total score of 103 with average 3,69. So with the results of the validation model is said to be very good. Further validation is conducted on SAP (Lecture Schedule), validation is conducted on a scale of 4 with a total of 17 indicators, obtained the total score of 62 and obtained an average of 3.63. Thus SAP validation results are said to be very good. Material validation is conducted with the number of 20 indicators obtained the number of scores 74 and the average obtained value 4, thus the validation of material experts related to teaching materials can be said very well. Validation of source criticism work sheet with scale 4 and number of indicators 13 got score 49 with average 3,78 thus it can be concluded the source critic's worksheet is said to be very good. From the results of validation by a team of local history learning experts using the archive-document can be applied in learning.

In experimental research, the researchers are not assisted by the lecturers in the implementation of the classroom learning model. Experimental research is used as a method of research method to find the effect of certain treatments on others in controlled conditions [20]. In this case the experimental class is the class given treatment and the result will be compared to the control class (which is not given treatment).

Based on the implementation process of learning model in the experimental class obtained some findings in the learning process, especially the activities undertaken by the students. Students are student centered, education provides only introduction, explains the learning model used and explains the tasks that must be conducted by the students. Furthermore, students work on the source criticism sheet in groups and make the framework of writing, the educator provides the source of the archives-documents and the required resources but the students are still given the freedom to add another source of learning process in the classroom through group discussion, cooperative approach where learning Which focuses on the use of small groups of students to work together in maximizing learning conditions to achieve learning objectives [20]

In the source criticism process of history and analysis, students discussed with their group to get new facts findings, in this process the historical research methodology has begun to appear with the help of learning materials in the form of hand out. Hand out is important points of instructional material, if used will not create a flick, making hand out for the learners to make learning more guided. Hand out has several functions such 
as those of Steffen and Peter Ballstaedt in Prastowo that the hand out function is, as a companion to the educator's explanation, as a learner's reference, a reminder of the subject matter taught, gives feedback and assesses learning outcomes. With the hand out of participants used in learning will be able to support the implementation of learning well and smoothly.

The experiments conducted by researchers ranging from small group test with the number of students 6 people with a mean of 3.7 which means it is good. Furthermore, large group test with the number of students 12 people with 24 indicators then obtained a mean 3.5 which means it is good and has increased from previous trials, but still need to conduct a revision.

\section{EFFECTIVENESS OF LEARNING MODEL USING DOCUMENT ARCHIVE}

To calculate the effectiveness of the developed model then firstly tested the equivalence between the class selected as the experimental class and control class, after that prerequisite test that is by looking at normality and homogeneity of data after all pre-analysis assumption analyzed then conducted effectiveness test by using $\mathrm{T}$ test.

The effectiveness test of the learning model is carried out on fifth semester students who temporarily take the local history course. The number of students on the effectiveness test of the learning model is 33 students. The use of documentary archives in college learning is very important, especially in history students either in History or in History. The archive-document has an important role in the writing of history in accordance with the archive role that is very important for researchers and historians to trace an event; the archive is a historical memory that can be used as a source of history to find facts in research and in the writing of scientific papers.

In equality test, the both groups (experimental class and control class) that are statistically comparable must be in the same or equivalent condition before treatment is given. In order to know the initial state, the pretest for both groups (experimental class and control class) is applied and the results are used as data to test equality. Briefly through calculation with SPSS 20 then equality test result presented as follows:

TABLE. 1. EQUALITY TEST

\begin{tabular}{|c|c|c|c|c|c|c|}
\hline & \multicolumn{6}{|c|}{ Test Value $=0$} \\
\hline & \multirow[b]{2}{*}{$\mathrm{T}$} & \multirow[b]{2}{*}{ Df } & \multirow[b]{2}{*}{ Sig. (2-tailed) } & \multirow{2}{*}{$\begin{array}{l}\text { Mean } \\
\text { Difference }\end{array}$} & \multicolumn{2}{|c|}{$\begin{array}{l}\text { 95\% Confidence Interval of the } \\
\text { Difference }\end{array}$} \\
\hline & & & & & Lower & Upper \\
\hline $\begin{array}{l}\text { Pre-test scores of experimental } \\
\text { class }\end{array}$ & & 3 & .000 & 43.000 & & 47.68 \\
\hline Pre-test score of control class & 51.820 & 3 & .000 & 44.250 & 41.53 & 46.97 \\
\hline
\end{tabular}

Based on the result of the analysis, it is known that the significance of 0.00 is less than 0.05 , then there is no significant difference or can be briefly seen from the average difference between the control class and the experimental class or equel. Prerequisite Test

Before performing hypothesis test with statistic calculation there are some requirements that must be fulfilled before conducting analysis, among others:

Normality test 
Normality test in this case using columnogorov-simirnov test by SPSS20. This test is intended to determine whether the sample is normal or not. The columnogorovsimirnov test looks at the 0.05 significance level when the significance is greater than 0.05 meaning that the sample is from a normally distributed population. Here is an analysis result using SPSS20:

TABLE 2. NORMALITY TEST

\begin{tabular}{|ll|l|l|}
\hline & & $\begin{array}{l}\text { Post-test score of } \\
\text { experimental } \\
\text { class }\end{array}$ & $\begin{array}{l}\text { Post-test score of } \\
\text { control class }\end{array}$ \\
\hline $\mathrm{N}$ & Mean & 4 & 4 \\
Normal Parameters & a,b & 83.00 & 67.25 \\
& Std. Deviation & 4.967 & 2.217 \\
Most Extreme Differences & Absolute & .250 & .214 \\
& Positive & .210 & .214 \\
& Negative & -.250 & -.155 \\
Kolmogorov-Smirnov Z & & .500 & .427 \\
Asymp. Sig. (2-tailed) & & .964 & .993 \\
\hline
\end{tabular}

Based on the results above, it showed a significance level of $0.964>0.05$. This means that the sample used in this study comes from a population that is normally distributed because it has met the assumption of test of normality Kolmogorovsimirnov.

Homogeneity test was conducted to find out whether the population variance is the same or not, the homogeneity test result using SPSS20 is presented in the following table:

TABLE 3 HOMOGENITY TEST

\begin{tabular}{|l|l|l|l|l|l|}
\hline & Sum of Squares & Df & Mean Square & F & Sig. \\
\hline Between Groups & 496.125 & 1 & 496.125 & 33.541 & .001 \\
Within Groups & 88.750 & 6 & 14.792 & & \\
Total & 584.875 & 7 & & & \\
\hline
\end{tabular}

Based on the above results a significance value of $0.01<0.05$ thus the variance of the study population is the same or homogeneous.

The experimental design used in this study using the $\mathrm{T}$ test statistic using spss 20 help, can be seen as follows: 
TABLE. 4. HYPOTHESIS TEST

\begin{tabular}{|c|c|c|c|c|c|c|c|c|c|}
\hline & \multicolumn{2}{|c|}{\begin{tabular}{|l|}
\multicolumn{2}{|l|}{ Levene's } \\
Test for \\
Equality of \\
Variances
\end{tabular}} & \multicolumn{7}{|c|}{ t-test for Equality of Means } \\
\hline & \multirow[b]{2}{*}{$\mathrm{F}$} & \multirow[b]{2}{*}{ Sig. } & \multirow[b]{2}{*}{$\mathrm{T}$} & \multirow[b]{2}{*}{ df } & \multirow{2}{*}{$\begin{array}{l}\text { Sig. } \\
(2- \\
\text { tailed })\end{array}$} & \multirow{2}{*}{$\begin{array}{l}\text { Mean } \\
\text { Difference }\end{array}$} & \multirow{2}{*}{$\begin{array}{l}\text { Std. Error } \\
\text { Difference }\end{array}$} & \multicolumn{2}{|c|}{$\begin{array}{l}95 \% \\
\text { Confidence } \\
\text { Interval of the } \\
\text { Difference }\end{array}$} \\
\hline & & & & & & & & Lower & Upper \\
\hline $\begin{array}{ll}\text { Post-test } & \text { Equal } \\
\text { score of } & \text { variances } \\
\text { source } & \text { assumed } \\
\text { criticism } & \text { Equal } \\
& \text { variances } \\
& \text { not } \\
& \text { assumed }\end{array}$ & 1.336 & .292 & $\begin{array}{l}5.791 \\
5.791\end{array}$ & 4.150 & .001 & $\begin{array}{l}15.750 \\
15.750\end{array}$ & 2.720 & $\begin{array}{l}9.096 \\
8.306\end{array}$ & $\begin{array}{l}22.404 \\
23.194\end{array}$ \\
\hline
\end{tabular}

The result of SPSS20 analysis is significant at $0.04<0.05$ which means there is a significant difference between the experimental class and the control class, hence it can be concluded the criticism ability of the student source treated with the learning of local history using the archive-document (experimental class) Has a higher source criticism ability compared to the control class. From these results it can be concluded that the hypothesis of this study is accepted.

Based on the data it has been obtained that the average score of criticism test of the source on the students using the developed learning model (experimental class) is 43 on the pretest and 83 on the post-test while the students who did not use the developed model (control class) showed pre-test value 44.25 and the post-test value of 67.25.

The use of archives-documents in learning is very important, especially history students either historical science or educational history. The archive-document has an important role in the writing of history in accordance with the archive role that is very important for researchers and historians to trace an event; the archive is a historical memory that can be used as a source of history to find facts in research and in the writing of scientific papers.

The use of project based learning archive-based documents in the learning of local history in students to improve the ability of source criticism in the students get the desired results, the application of this learning model shows improvement of criticism ability of the source of the students it is seen with the effectiveness test results conducted by researchers with Compare the ability of the experimental class (treated class) and the control class (the untreated class). In post-test experimental class obtained average higher than the result of post-test control class then the value is reinforced by conducting the T test using SPSS20 statistical program help so that the results obtained with a significance of $0.04<0.05$ thus the ability of the source point students who are given treatment by model developed higher than the students do not give treatment. In the post-test result of experiment class also obtained average higher than result of posttest control class then the value is reinforced by conducting $\mathrm{T}$ test using spss 20 statistical program aid so that obtained result with significance with $0.04<0.05$ thus hence ability of student source point given treatment with a model developed higher than those not treated. 
Source criticism is part of the historical research methodology; the student's criticism ability will influence a range of historical research methods that are a unified component of Heurustics, source criticism, interpretation, and then historiography. The method of historical research is a way to reconstruct a historical event into a meaningful and historical event. Source criticism is performed to verify to test the authenticity or originality of the source and to assess whether the source has credibility or not [13]. This is in line with what L. Gottschalk reveals that the source criticism of history is an attempt to gain the authenticity and credibility of the source by doing intellectual and rational work that follows the historical methodology in order to gain the objectivity of an event. Thus it can be said that the model of learning that is applied as an effort to improve the ability the historical source criticism of the students is important to do.

The relevant previous research results associated with research conducted, namely, research conducted by Burcak. In this study explained that the archive is a primary source for educators and students and even the wider community. In this study more emphasis on the use of archives as a primary source and historical value, thus archives have the ability to bridge the past, historical phenomenon with the present. By entering the archive as the primary source of learning, students will be easier to understand and work on their history project, because in addition to books, the primary source will make it easier for students to be trained in narrating a historical project by evaluating the original, formulating arguments and learning to maintain arguments. They are about the past. In addition, the archive as a primary source can train students to be able to recognize historiography, interpret evidence, and students will be able to form information in the form of their own opinions that are not the same as information obtained from printed books.

Other research on the use of archives-document is carried out by Muslichah. In the explanation, the archive has the potential that can be utilized as an educational media in building the character of the nation by presenting in a variety of positive propaganda packaged in a tour package. Positive propaganda in question is to explore the positive information contained in the archives such as the history of the struggle, history of nationality, and so forth. The information is poured in the media representative with communicative language, the media used can be, books, posters, films, and others. The information presented should be able to display educational values, able to build selfawareness, and most importantly able to encourage and motivate to actualize these values in private life, community, nation and state.

The lessons developed in this study have advantages such as will be able to form a free intellectual environment for students, in which case they are free in exploring the local history that comes from the archives of the sultanate of Bima. Students will be more active using primary sources in the writing of history and other scientific works. The learning model developed positioned the students more actively during the learning process. The use of the document archive as a learning resource will provide a new experience for students so that it will lead to the use of structured historical research methods. Students will be closer to the primary source of history.

\section{CONCLUSION}

The effectiveness of archive-document use project based learning in local history learning to improve the students' criticism ability was conducted in the control class and 
experimental class by the equality test between the class chosen as the experimental class and the control class, after which the prerequisite test was conducted by looking at normality And the homogeneity of data after all pre-analysis assumption analyzed then effectiveness test by using $\mathrm{T}$ test from effectiveness test result which use of learning model developed can increase the ability of students' source criticism which can be seen from improvement of learning result before (pre-test) and after test in the learning conducted (post-test), it can be seen from the difference between the control class (which is not treated) and the experimental class (treated), on the post-test result of experimental class got higher score than the control class. The statement is proved based on the analysis through $\mathrm{T}$ test. From $\mathrm{T}$ test result, it can be obtained with a significance of $0.04>0.05$ thus the ability of students' source criticism who are given treatment with a model developed higher than students who are not given treatment. This means that the developed model can improve students' source criticism. So this learning model using PJBL-based document-based archive tested feasible can be utilized by lecturers in local history learning in accordance with the materials given.

\section{REFERENCES}

[1] Abdullah, Tauflk. 2001. Nasionalisme dan Sejarah, Bandung: Satya Historika.

[2] Agung, Leo. Wahyuni, Sri. 2013. Perencanaan Pembelajaran Sejarah.Yogyakarta:Ombak.

[3] Borg and Gall. 1989. Educational Research: An introduction (5 $5^{\text {th }}$.ed) New York: Longman.

[4] Grant Bage, 1999. Narative Matter: teaching and learninaag history though story. New York: Falmer Press Routledge.

[5] I Gde Widja. 1989. Sejarah Lokal suatu Perspektif dalam Pengajaran Sejarah. Departemen Pendidikan dan Kebudayaan, Direktorat Jenderal pendidikan Tinggi. Jakarta

[6] Isjoni. 2014. Cooperative Learning. Bandung : Alfabeta

[7] Joyce, Bruce., Marsha Weil., \& Emily Calhoun. 2009.

[8] Kartodirdjo, Sartono. 2014. Pemikiran dan perkembangan historiografi Indonesia. Yogyakarta: ombak

[9] Kochhar. 2008 .Teaching of History. Pembelajaran Sejarah(terj.) Purwanta. Jakarta : PT. Gramedia

[10] Lohanda, Mona. 2011. Membaca Sumber Menulis Sejarah. Jogyakarta : Ombak

[11] Mudjiono.2013. Belajar dan Pembelajaran. Jakarta : PT. RINEKE CIPT

[12] Ngalimun.2014. Strategi dan model Pembelajaran. Yogyakarta: Aswaja Persindo

[13] Priyadi, Sungeng. 2012. Sejarah Lokal. Yogyakarta: Ombak

[14] Purwanto, Bambang. 2006. Gagalnya Historiografi Indonesia. Yogyakarta : Ombak

[15] Sambas, dkk. 2007. Analisis antara Korelasi, Regresi dan Jalur dalam Penelitian. Bandung: CV Pustaka Setia.

[16] Schunk, Dale H. 2012. Learning Teory An Educational Perspective. Yogyakarta. Pustaka Pelajar.

[17] Sjamsuddin, Helius. 2012. Metodologi Sejarah. Yogyakarta: Ombak

[18] Slavin, E. Robert. 2009. Cooperative Learning Teori, Riset dan praktik. Nurulita(penj.) Bandung : Ujung Media

[19] Slameto. 2003. Belajar dan Faktor-faktor yang Mempengaruhi. Jakarta : Rineka Cipta.

[20] Sugiyono. 2002. Statistik Untuk Penelitian. Bandung: Alphabet.

[21] Anonim. 2015. Metode Penelitian Pendidikan: Pendekatan Kuatitatif, Kualitatif, dan RND. Bandung : Alfabeta

[22] Sujarwo. 2011. Model- Model Pebelajaran: Suatu Strategi Mengajar. Jogyakarta: Venus Gold Press

[23] Susanto, Heri. 2014. Seputar Pembelajaran Sejarah. Jogyakarta. Aswaja

[24] Sumadi. 2002. Proses Belajar Mengajar di Sekolah. Jakarta: Rineka Cipta. 
[25] Trianto. 2012. Mendesain Model Pembelajaran Inovatif Progresif;Konsep,Landasan, dan Impementasi pada Kurikulum Tingkat Satuan Pendidikan (KTSP). Jakarta. KENCANA

[26] Wahyono, Teguh. 2004. Sistem Informasi: Konsep Dasar, Analisis Desain dan Implementasi. Yogyakarta: Graha Ilmu

[27] Alfian, Magdalia. 2011. Pendidikan Sejarah Dan Permasalahan Yang Dihadapi. dalam Jurnal Ilmiah Kependidikan, Vol. III, No. 2, Maret.

[28] Alamsyah. 2014. Relavansi Arsip dan Sejarah dalam proses pembentukan karakter bangsa. Jurnal HUMANIKA volume. 19 No. 1 tahun 2014 ISSN:1412-9418

[29] Burcak. 2013. The Use Of Archives In Education : Examples From Abroad. International Journal on New Trends in Education and Their Implications January 2013 Volume: 4 Issue: 1 Article: 10 ISSN 1309-6249

[30] Dimyanti. 2015. A Study of Education History on Giffed Children: Reaserch on Their Learning Achievement as They Started Their School Under Seven. EDUCARE: International Journal for Educational Studies, 8(1) August.

[31] Gunarto, Imam., 2010 "Memahami Arsip dari Filsafat Ilmu: Kajian Awal tentang Ilmu Kearsipan" dalam Jurnal Kearsipan, Volume 5, ANRI.

[32] Heryatun, Yayu. 2013. How Students Make Meaning From Literary Text?. EDUCARE: International Journal for Educational Studies, 6(1) August.

[33] Jurnal kearsipan ISSN 1978 130X vol 7/ANRI/12/2012

[34] Lohanda, Mona., 2010 “Mengenal Sumber Sejarah" dalam Jurnal Kearsipan, Volume 5, ANRI.

[35] Nordin, Norshidah. 2014. Do Academic Leaders Matters? A Study on Transformational Leadership Behavior in a Higher Learning Institutuion. EDUCARE: International Journal for Educational Studies, 7(1) August.

[36] Priyanto, Eko. 2014. Improving Democratic Values in Civic Education Learning Through Grouped-Discussion Method for the Students in Higher education Institution. EDUCARE: International Journal for Educational Studies, 6(2) February.

[37] Sahat, Benedictus. 2014. Pentingnya pengarsipan arsip pemilu dalam menunjang pemilu yang jujur dan adil. Jurnal RECHTSVINDING:Media Pembinaan Hukum Nasional volume 3 No.1 April 2014 ISSN:2089-9009

[38] Sartini. 2011.Guna Sejarah: Mengapa Harus Belajar Sejarah. Dalam jurnal SOSIO e-KONS. Vol II No. 4 November-Januari 2011

[39] Sudaryat, Yayat. 2014. The Interpretation of Sundanese Educational Philosophy in Traditional Idiomatic Expressions. EDUCARE: International Journal for Educational Studies, 6(2) February.

[40] Supardan,.Dadang. 2009. Pembelajaran Sejarah Berbasis Pendekatan Multikultural dan Perspektif Sejarah Lokal, Nasional, Global, dalam Integritas Bangsa (studi kuasi Eksperimental terhadap siswa Sekolah Menengah Atas di Kota Bandung). Dalam Jurnal Universitas Indonesia.

[41] Supriatna, Nana. 2011. Konstruksi Pembelajaran Sejarah yang Berorentasi pada Maslah Kontenporer Pembengunan. MIMBAR, Vol.XXVII, No. 1 Juni:21-30

[42] Waluyo. 2009. Sadar Arsip dan Kesadaran Sejarah. Dalam buletin Khazanah, Tanggal 6/112009. 